transverse rows. The liver of Avahis is represented without any gail-bladder (it may be embedded), this viscus being large, and having, as in the typical lemurs, its fundus reversed from its ordinary position, and buried in the hepatic issue in the two other genera. The caudate lobe of the liver is absent, and the spigelian is of fair size. These points, it may be mentioned, have been previously recorded by Prof. Flower in his Hunterian Lectures before the College of Surgeons in 1872 , on the visceral anatomy of the Mammalia. In Propithecus the left subclavian artery is shown to be given off from the innominate trunk, whence spring the three other main anterior vessels, whilst in Avahis and Indris it springs independently from the aorta. As in the other Lemurs and the Swine, the mesenteric arteries run straight to the walls of the viscera they supply, and do not form loops just before they reach them; they anastomose freely at their origins.

M. Milne-Edwards gives as the dental formulæ of the Indrisina the following :---

$$
\begin{aligned}
& \text { Milk dentition .. } i \frac{2}{2} c \frac{\mathrm{I}}{\mathrm{I}} m \frac{2}{3}=22 \\
& \text { Permanent dentition . } i \frac{2}{2} c \frac{\mathrm{I}}{0} p m \frac{2}{2} m \frac{3}{3}=30
\end{aligned}
$$

Whether or not this method of expressing the dentition is correct is a matter of uncertainty, it depending on the nature of the outer lower cutting teeth of the typical Lemurs. We cannot, with many zoologists, help retaining the opinion that the outer lower incisor-like teeth of Lemin and its nearest allies are canines, and they most certainly represent the outer pair in Indris, in which they are larger than the inner. The presence of a third lower milk molar confirms the opinion expressed by Prof, Huxley ${ }^{1}$ in his mernoir on the Angwántibo (Arctocebus calabarensis), that in the adult Indrisinæ it is a premolar which is missing in each semi-jaw.

M. Milne-Edwards gives elaborate measurements of the bones of the three genera, which are also represented in the graphic form, on ordinates, by which means excellent comparisons can be made at a glance.

In the myological section of the work, the contributions by Vrolik on Stenops, Messrs. Mivart and Murie on Nycricibus and the Lemuroidea generally, Van Campen and Van der Hoeven on the Potto, Burmeister on Tarsizs, and Prof, Owen on the Aye-Aye are employed for comparison, and the whole monograph has filled the only important gap, till now vacant, in our knowledge of the anatomy of the Lemurs.

\section{SCIENCE AND ART IN IRELAND}

$A \mathrm{~N}$ important announcement as to the proposed action id of the Government with regard to the various scientific institutions in Dublin is contained in the following articie, which we reprint from the Times of Tuesday last:-

'T'he subject of the administration of Science and Art in Ireland in connection with increased State aid has now been under discussion at different times for many years. it must not be imagined, however, that Ireland is not already provided with numerous institutions for the promotion of Science and Art, or that it lacks grants for that purpose. In Dublin alone there are under the management of the Royal Dublin Society, which is a chartered body, a Museum of Natural History, Botanic Gardens (with Botanical Museum), and a library. Next comes a purcly national institution, the Royal College of Science, with its small industrial collections and the geological collections of the Geological Survey. On the borderland of Science and Att we have the Royal Irish Academy, with its library and Antiquarian Museum, containing the richest collection of Celtic antiquities existing out of Copenhagen, including the celebrated Tara Brooch and Tara "torques," and the Cross of Cong.

\footnotetext{
I Proc. Zcol. Soc., x864, p. 327 .
}

Coming to the region of Art pure, we have the School of Art, under the management of the Royal Dublin Society; the Royal Hibernian Academy, corresponding to our own Royal Academy (which also has its School of Art) ; and lastly, the Irish National Gallery. So far as we can gather from the estimates, the total grant to Science and Art Institutions in Dublin is upwards of $25,000 \%$. a year, though it is difficult to obtain very precise information on this head, as the votes are taken, some by the Science and Art Department, some by the Treasury, and some by the Office of Works.

The Library, the Natural History Museum, and the Botanic Gardens have since 1865 been entirely supported by the State, though managed by the Dublin Society acting as trustees, while the collections of the Royal Irish Academy, which receive an annual subsidy of about 2,000 . besides a house, have been very largely purchased out of public funds. The Royal Dublin Society has of late years devoted its energies and its private funds most usefully in furtherance of agriculture. The Royal Irish Academy not only covers the field of the Royal Society of England, but also ttakes under its care literature and antiquities.

It will thus be seen, to compare the State supported institutions in Dublin with those in London, that the elements of the British Museum, the Geological Museum, the South Kensington Museum, the National Gallery, and Royal Academy exist in Dublin, to say nothing of the Royal College of Science, which has a more complete course than our own School of Mines. In spite, however, of the number of these institutions, and, in fact, because of their number, the collections, whether of books, natural history specimens, or antiquities, have not had the completeness which one would expect. While on the one hand many have been inconveniently housed, on the other the Government has naturally felt a difficulty in improving their condition so long as they were in the hands of more or less irresponsible private bodies, and hence the many attempts to bring about a consolidation, to which we may briefly refer.

Thus we find that in I 862 the Treasury appointed a small Commission, with Sir C. Trevelyan as chairman, which made certain recommendations. Before these were acted on, however, the subject was, in I864, taken up by a Committee of the House of Commons, of which Mr. Gregory was chairman. This body dissented widely from the views expressed by the Treasury Commission, and thus the matter rested till I 868 , when the Government decided to constitute a separate Department of Science and Art for Ireland, "analogous in its constitution to the existing Science and Art Department in London for the United Kingdom;" and appointed a Committee, of which the Duke of Leinster, then Marquis of Kildare, was chairman, to report on the best means of carrying out the project.

The Committee, having upon it such representative Irish members as the Marquis of Kildare, the Very Rev. Dr. Russell, the then President of Maynooth, the Rev. S. Haughton, and Mr. G. A. Hamilton, the then Secretary of the Treasury, soon found it impracticable to organise such an independent department as had been contemplated, and applied for an enlargement of their instructions ; in fact, it became evident very early in the inquiry that all but a small minority in Ireland were in favour of continuing the connection with the English Department. Teachers and students specially petitioned that the connection might be maintained, as they saw clearly that the severance would deprive them of the highest rewards and best promises of a career by cutting off the English field from them. However much some may regret the fact, the fact remains that in all vocations the highest talent will seek the place where it is most highly prized and rewarded, which in the case of the United Kingdom means London. 
Acting upon this and other considerations, to which we need not further allude, the Commission unanimously came to the conclusion that the remedy they were seeking lay, not in the formation of a separate Department for Ireland-which, indeed, they went on to say would be detrimental to the interests of Science and Art in that country-but in the consolidation and better administration of the existing institutions, and in the filling up of some obvious gaps, The essence of their recommendations was the amalgamation of several of the collections into an institution strongly resembling the South Kensington Museum, but covering a wider field, which should be administered by a director, who should be in immediate relation not only with the Minister of Education, but also with the Irish Government. This scheme, however, had a great drawback in the eyes of many of the leading noblemen and gentlemen in Ireland who were interested in the existing institutions, because it entailed the deprivation in the case of the two principal societies - the Royal Dublin Society and the Royal Irish Academy - of the privileges they had hitherto enjoyed of administering large public funds voted for the Natural History Museum and the Botanic Gardens, as well as other institutions. This objection and, possibly, the economical views of the late Government, have sufficed to keep this question in abeyance since 1868 ; but it now appears that the present Government have determined to take some decided step, for they have, we understand, during the last few days communicated with the bodies principally intercsted in the scheme.

From the information which has reached us we gather that the plan now proposed is as complete as that indi-

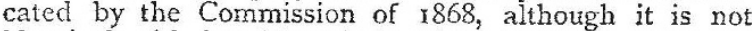
identical with it. Thus it has been decided to build a Science and Art Museum for Ireland similar to that now existing in Edinburgh. This will occupy a site adjacent to the principal buildings which now exist, and will consist of collections analogous to those of the South Kensington Museum, to which will be added the antiquarian collection of the Royal Irish Academy, and the industrial collection of the old Museum of Irish Industry. The building will also provide space for the Natural History Museurn and Geological Collection, and will thus set free the present Natural History Museum, to which the library of the Royal Dublin Society will be transferred and formed into a public National Library.

As may be imagined, this comprehensive scheme will entail the expenditure of a large amount of public money, and the Government make the offer contingent on the surrender of the privileges to which we have before referred, and the vesting of all the property in the Government. With the view, however, of still enabling those who at present take so great an interest in the existing institutions to continue this useful co-operation and represent the special wants of the country, it is proposed that the new National Library shall be managed by a Council of twelve trustees-eight to be nominated by the Royal Dublin Society and four by the Government; while the administration of the Science and Art Museum, which is to be under a director appointed by the Crown, as in Scotland, will be controlled by a Board of twelve visitorsfour nominated by the Lord Lieutenant; five by the Royal Dublin Society; and three by the Royal Irish Academy.

It is not proposed to interfere with the functions of the societies we have named, and we are glad to see that the Government propose still to continue the aid they now give to them.

In making these proposals the Government has taken the opportunity of putting on record its appreciation of the eminent services which have been rendered to both art and science by the societies we have named, and makes it clear that the motive for suggesting any diminution of their independence is, that the wants of the com. munity with regard to such matters as public museums have now in Ireland, as long ago in England, outgrown the useful operation of private societies.

The surrender of what we may, we hope, without offence, term some of their ornamental functions, will no doubt be somewhat painful to their members; but we cannot suppose that they will allow their private feeling to stand in the way of a national scheme so rich in promise, and based on principles which we should be glad to see applied in other localities besides Dublin.

\section{MINIATURE PHYSICAL GEOGRAPHY}

THE sands of the Lower Bagshot series are exposed along the shore at Bournemouth and form the cliffs. They are agglutinated into a very friable sandstone, which

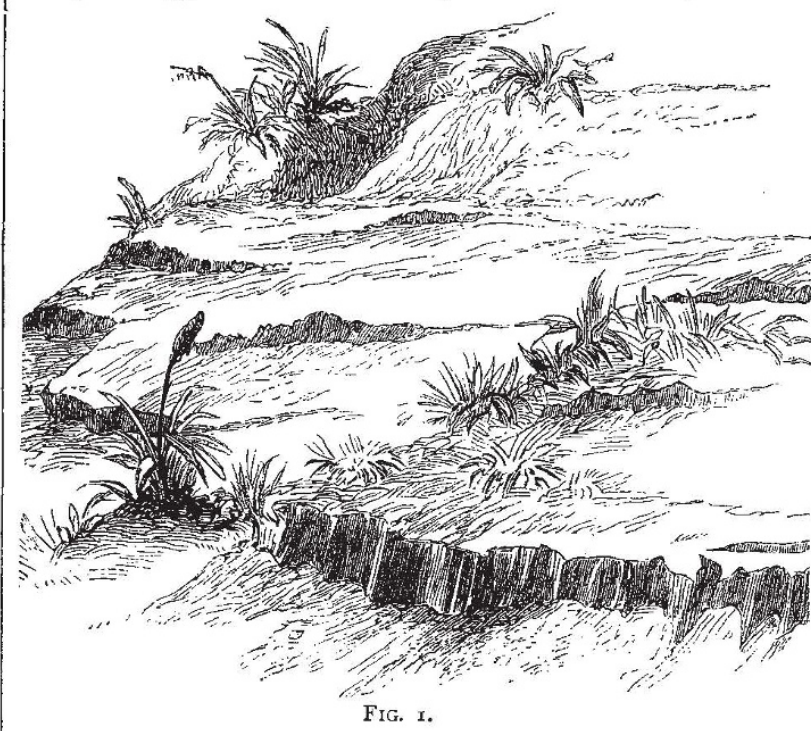

disintegrates under the influence of rain with extreme readiness. The siliceous grains are cemented together, probably by carbonate of lime. At any rate the adhesion of particle to particle is very slight and easily relaxed.
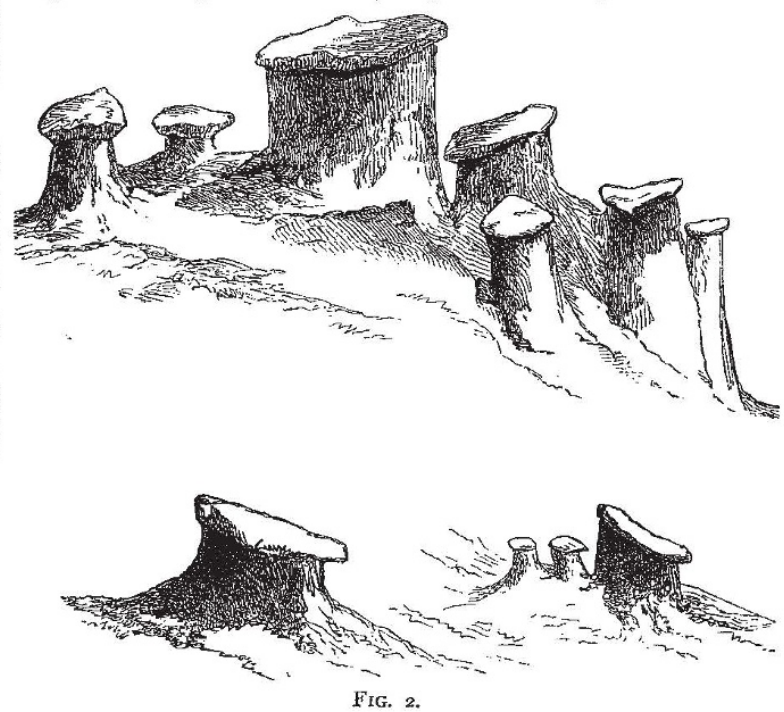

The result is that phenomena of erosion which elsewhere take years, centuries, ages, display themselves here on a miniature scale, and in a very short space of time. All the details of a river drainage system may be seen 